\title{
A conceptual model of psychological contracts in construction projects
}

\author{
Yongjian $\mathrm{Ke}^{1}$, Peter Davis ${ }^{2}$ and Marcus Jefferies ${ }^{2}$ \\ ${ }^{1}$ School of the Built Environment, University of Technology Sydney, Australia \\ ${ }^{2}$ School of Architecture and Built Environment, University of Newcastle, Australia
}

\begin{abstract}
The strategic importance of relationship style contracting is recognised in the construction industry. Both public and private sector clients are stipulating more integrated and collaborative forms of procurement. Despite relationship and integrated contractual arrangement being available for some time, it is clear that construction firms have been slow to adopt them. Hence it is timely to examine how social exchanges, via unwritten agreement and behaviours, are being nurtured in construction projects. This paper adopted the concept of Psychological Contracts (PC) to describe unwritten agreement and behaviours. A conceptual model of the PC is developed and validated using the results from a questionnaire survey administered to construction professionals in Australia. The results uncovered the relationships that existed amongst relational conditions and relational benefits, the PC and the partners' satisfaction. The results show that all the hypotheses in the conceptual model of the PC are supported, suggesting the PC model is important and may have an effect on project performance and relationship quality among contracting parties. A validated model of the PC in construction was then developed based on the correlations among each component. The managerial implications are that past relationships and relationship characteristics should be taken into account in the selection of procurement partners and the promise of future resources, support and tangible relational outcomes are also vital. It is important for contracting parties to pay attention to unwritten agreements (the PC) and behaviours when managing construction projects.
\end{abstract}

Keywords: Psychological contracts, contracting behaviour, conceptual model, construction, Australia.

Submission type: Research article

\section{Introduction}

The construction industry is one of the single most important industries in the Australian economy in terms of its contribution to growth of the economy. According to the Australian Bureau of Statistics (2015), the construction industry was the second largest contributor to the Australian Gross Value Added in the year 2014-15. The quality of the construction product is closely linked to performance of building and property in the wider socio-economic community it serves (Chan and Chan, 2004). Yet, the Australian construction industry is inefficient (Fulford and Standing, 2014). Using simple labour productivity measures, value added per worker in construction ranks ninth out of 18 industries (Richardson, 2014). A major contributing factor to this inefficiency is due to adversarial relationships that exist within the construction industry (Fulford and Standing, 2014; Smiley, Fernie and Dainty, 2014). Effective participation in relationship development has the potential to significantly reduce transaction costs in projects (Ke, Ling and Zou, 2015).

Copyright: Construction Economics and Building 2016. C 2016 Yongian Ke, Peter Davis and Marcus Jefferies. This is an Open Access article distributed under the terms of the Creative Commons Attribution 4.0 Unported (CC BY 4.0) License (https://creativecommons.org/licenses/by/4.0/), allowing third parties to copy and redistribute the material in any medium or format and to remix, transform, and build upon the material for any purpose, even commercially, provided the original work is properly cited and states its license.

Citation: Ke, Y., Davis, P. and Jefferies, M. 2016. A conceptual model of psychological contracts in construction projects, Construction Economics and Building, 16(3), 20-37. DOI: http://dx.doi.org/10.5130/AJCEB.v16i3.4993

Corresponding author: Yongjian Ke; Email - Yongjian.Ke@uts.edu.au

Publisher: University of Technology Sydney (UTS) ePress 
In addition, both public and private sector clients are calling for more integrated and collaborative forms of procurement, such as Alliance or Public Private Partnerships (Department of Infrastructure and Regional Development, 2015). Despite relationship and integrated procurement opportunities being available for some time, it is clear that Australian firms have been slow to adopt them and those that have participated have problems in articulating significant benefits (Walker, Harley and Mills, 2015). Collaboration and relationship management are considered the major factors contributing to the functioning of collaborative forms of procurement (Walker, Harley and Mills, 2015; Walker and Lloyd-Walker, 2015).

Given the emphasis on the impact of relationships in construction literature (Cheung, Yiu and Chim, 2006; Davis and Love, 2011; Fulford and Standing, 2014; Walker, Harley and Mills, 2015), the following research question becomes noteworthy: how are relationships being nurtured in construction projects? In order to focus the findings, this research is limited to non-contractual agreement and behaviours, excluding contractual agreement and behaviours. Non-contractual behaviours are those that are not defined in the contractual documents and contracting parties are able to practice to a different extent according to their will (Sariola and Martinsuo, 2016). The reason is that non-contractual agreements and behaviours can better demonstrate the shared perceptions of contracting parties regarding practices that affect relationships in construction projects. In context this research adopts the concept of Psychological Contract (PC) mainly developed by Rousseau (1990) to explain non-contractual agreement and behaviours, which is defined as "individual beliefs in reciprocal obligations between employees and employers". Accordingly, this research aims to investigate whether the concept of PC can be applicable to the upstream (for example a client) or downstream (for example a specialist contractor) organisational relationships among procurement partners, and whether the PC can be adopted as a suitable framework to explore organisational relationships, thereby responding to the research question: how are relationships being nurtured in construction projects?

\section{Literature review}

\section{Relationships in construction}

Doloi (2013) described that traditional contracting is one method within a procurement continuum for delivering projects in construction, in which formal contracts are used to enforce the obligations and rights among contracting parties (Cheung, Yiu and Chim, 2006). The relationship in a traditional construction project hence has a low degree of rationalism, often resulting in a difference of opinions on project issues (Love et al., 2011). Such contractual relationships support a common mantra being "your loss is my gain", which generates a variety of inefficiencies during project delivery (Doloi, 2013). Accordingly, there is a call for radical cultural change to reduce adversarial conflicts and increase productivity levels through integration of fragmented functions and different team working approaches (Rahman and Kumaraswamy, 2004; Lloyd-Walker, Mills and Walker, 2014).

Relational contracting is based on recognition of mutual benefits and win-win scenarios and involves cooperative relationships between contracting parties (Rahman and Kumaraswamy, 2004). A range of relational contracting approaches have been implemented across many countries to facilitate deeper collaborative relationships, such as partnering, alliance and public private partnership. Lahdenperä (2012) compared three different contractual arrangements including partnering, alliance and integrated project delivery and concluded that the core of philosophy in three arrangements is to generate a cooperative and trustful climate for implementation for the best of the project. Similar findings are observed in Ling et al. (2014a) and $\mathrm{Lu}$ et al. (2015) suggesting that relational governance can improve the relationships among contracting parties, thereby improving project performance in construction projects. 
Apart from the mentioned procurement approaches in studying relationships, individual research has also been performed to identify certain factors or elements which may affect relations and bonds between the parties in construction (Jelodar, Yiu and Wilkinson, 2016). Attributes such as trust and mutual goals can also effect collaboration and relationships (Meng, 2010). Jin and Ling (2005) developed a framework for fostering trust and building relationship. Wong et al. (2008) categorized three major types of trust: system-based, cognition-based and affect-based trust. Accordingly, because of the formal and structured focus to relationships in construction projects, contracting strategies such as the commitment, mutual trust and cooperation have been developed to fulfil the relational prerequisite (Ke, Ling and Zou, 2015).

\section{Psychological Contract (PC)}

The term PC refers to the unwritten expectations of an employment relationship as distinct from the formal codified employment contract. It first gained popularity in human resource studies during the 1990s (Rousseau, 1990; Rousseau, 1995; Sparrow and Marchington, 1998). The basis of the PC relationship within a firm is reciprocity between the organization and employees on the perceived obligations and expectations from one another (Guest and Conway, 2002). What is clear is that as the PC evolves around individual beliefs and perceptions, it is highly subjective and can be particular to each employee (Rousseau, 1995). In essence, the PC constitutes an unwritten agreement between the organization and employees based on mutually accepted promises and obligations among the organization and the employees (Sparrow and Marchington, 1998). The PC theory has been widely adopted in many different sectors, such as education (Bordia, Bordia and Restubog, 2015), hospitality (Bashir and Nasir, 2013), and banking (Yang and $\mathrm{Fu}, 2013)$.

\section{PC in construction}

In 2004 a team of British academics first wrote about PC displayed by construction project managers (Dainty, Raiden and Neale, 2004). Dainty, Raiden and Neale (2004) investigated the dynamics that govern the PC between construction project managers and employees in order to understand its influence on employee turnover. Interestingly to the context of this research they identified that understanding based on trust in the PC was being undermined at the time by organisational change that encompassed flattened organisational structures and overall expansion (Raiden, Dainty and Neale, 2009). Studying employee resourcing in construction Raiden, Dainty and Neale (2009) observed inconsistencies due to a reliance on line management personal assessments. These decisions potentially disillusion employees through a violation of the psychological contract. As a result, a more flexible approach to employee resourcing in construction organizations was suggested, where individuals' preferences and expectations are taken into account throughout resourcing processes Raiden, Dainty and Neale (2009). Most recently, Dainty and Loosemore (2013) reinforced the link between the individualization of the employment relationship, productivity maximisation and the PC. They also noted that intrinsic rewards are becoming more important in the job market, citing an example from their case study where individuals involved on a construction project suggested that the PC offers scope for creativity, innovation and a feeling of long-term impact on their environment (Dainty and Loosemore, 2013).

Although the importance of relationships in construction has been extensively discussed in literature, non-contractual relationship-based agreement and behaviours are not distinguished from contractual arrangements. Non-contractual agreement and behaviours can better demonstrate the shared perceptions of contracting parties regarding relationships in construction, as they are able to practice to different extents according to will. Such noncontractual agreement and behaviours can be explained by the concept of PC, which has been widely adopted in many different sectors except construction. Beyond the above-mentioned 
limited body of scholarly writing, studies centred on the application of the PC in the construction industry have been largely unexplored, with the exception of recent interest specifically related to PC and workplace safety (Walker, 2010; Walker, 2013; Walker and Hutton, 2006). Consequently, it is not known whether the PC can be applicable to the upstream (for example a client) or downstream (for example a specialist contractor) organisational relationships among procurement partners. Accordingly, this paper focuses on the impact of the PC in construction projects. The specific objective of this paper is to develop a conceptual model of the PC to explore organisational relationships in construction projects. The proposed conceptual model will provide in-depth explanations to the research question: how are relationships being nurtured in construction projects?

\section{Preliminary conceptual model of the PC}

As described in the literature review, previous models of the PC displayed a relationship of exchange between an organization and an employee (Guest and Conway, 2004). Employee variables from the employee's perspective include a range of individual biographical and occupational factors, including type of employment contract, possible variations in orientations towards work and levels of job involvement. Organizational variables include human resource practices in place that might help to shape levels of trust and fairness. Adapting Guest and Conway's (2004) work, a preliminary conceptual model of the PC in construction was developed and is shown in Figure 1. The term PC in this paper refers to unwritten agreement and behaviours between a construction firm and its upstream or downstream procurement partners. The PC model in construction includes unwritten agreement and behaviours that are elaborated in the following subsections. The label number in each construct is the question number from the adapted questionnaire, which is explained in the Research Methodology. In the conceptual model, the relational conditions include past relationships and future appropriate resources and support; the relational benefits consist of perceived future tangible relational outcomes and intrinsic relationship characteristics benefits.

\section{Unwritten agreement}

Trust (Q19) is an important unwritten agreement amongst contracting parties in construction projects (Morgan and Hunt, 1994). Previous research indicates that the contributions of trust in construction contracting include improvements of time, cost and quality of construction projects, a reduction of adversarial relationships and the promotion of co-operation (Wong et al., 2008). Trust building is often connected with the principles of collaborative procurement methods (Davis and Walker, 2007). In a trusting relationship such as a PPP or an alliance, which represent the most integrated of delivery systems in a procurement continuum, stakeholders are able to focus on essential long-term benefits that include reduced conflict and maximised mutual benefits (Love et al., 2014). Other examples of long-term benefits are to provide enhanced competitiveness, innovation and productivity (Davis and Love, 2011). In the past a procurement partner's perception of trust has been measured using a scale developed by Morgan and Hunt (1994) to capture the level of reliability (participants do what they say), integrity and confidence.

Commitment (Q20) is closely aligned to trust, which is essential to long-term relationships and follows the conviction of contracting parties that remaining in the relationship would provide better outcomes than not (Morgan and Hunt, 1994; Leung, Yu and Chong, 2015). Commitment is contextualised in a similar way to mutuality, loyalty and the forsaking of others and is clearly distinguishable in long-term relationships (Gundlach, Achrol and Mentzer, 1995; Liu et al., 2014). Commitment of contracting parties keeps the team motivated, driven towards successful completion of the project (Jha and Iyer, 2007; Leung, Yu and Chong, 2015). It is often regarded as one of critical success factors in construction projects (Chen and Chen, 2007; Ling et al., 2014b; Liu et al., 2014). In the survey commitment scales were adapted from Gundlach, Achrol and Mentzer (1995). 




Figure 1: Preliminary conceptual model of the PC in construction 
Gundlach, Achrol and Mentzer (1995) suggested that relational social norms (staying together..., ...mutual benefit and trust..., ... accommodating one another...) are pivotal and underpin the commitment process. They produced an interesting perspective as a subset of questions that requested respondents to reflect on their procurement partner's good faith and fair dealing (Q21). Commitment depicts the level of honesty, professionalism and collegiality that a firm perceives from its upstream or downstream procurement partner. The implied duty of good faith and fair dealing has been described as the obligation to refrain from doing anything that will damage the right of the other party to receive the benefits (Wyse and Malik, 2005).

\section{Unwritten contracting behaviours}

In addition to all the contractual obligations (written terms of the contract), a construction contract may give rise to implied behavioural obligations. One such obligation is relational communication, which is defined as the formal and/or informal sharing of meaning and timely information between contracting parties (Cheng et al., 2001). This is measured using the scale developed by Leuthesser and Kohli (1995) to tap the extent of initiating (Q15), signalling (Q16) and disclosing (Q17) behaviours within relationships.

Leuthesser and Kohli (1995) defined initiating behaviour (Q15) as a downstream provider's advanced understand of specific needs of buyers. In an attempt to improve service quality, they help buyers obtain a competitive advantage. In a construction context, it refers to a firm that proactively take the initiative to better understand its procurement partner. For example, a construction firm makes an effort to learn how to help its procurement partner reduce costs, gain maximum benefit from its input, and essentially become more competitive.

Signalling behaviour (Q16) means that sellers actively inform the buyers of products and market information (Leuthesser and Kohli, 1995). In this research, it is interpreted that a construction firm gives its procurement partner ample notice of advance delivery schedules and any planned/unplanned changes in procedures, team makeup, service or quality of the product.

Disclosing behaviour (Q17) means that sellers would not conceal necessary information from buyers (Leuthesser and Kohli, 1995). In construction projects, it can be regarded as the extent that a construction firm reveals sensitive information about itself and/or its operations. For instance, a construction firm may openly talk about weaknesses in its organisation, provide a clear picture of what goes on behind-the-scenes, and communicates explicitly its expectations of its procurement partner.

\section{Hypotheses}

In light of the above, five research hypotheses are set out below.

H1: Better relational conditions and benefits would lead to a higher level of unwritten agreement between contracting parties;

H2: Better relational conditions and benefits would lead to a higher extent of unwritten contracting behaviours between contracting parties;

H3: When the level of unwritten agreement between contracting parties increase, unwritten contracting behaviours are adopted to a greater extent;

H4: A higher level of unwritten agreement between contracting parties would lead to a higher satisfaction; and

H5: A higher extent of unwritten contracting behaviours between contracting parties would lead to a higher satisfaction. 


\section{Research method}

A structured questionnaire survey was adopted to collect data to test the above-mentioned hypotheses from the preliminary conceptual model. A robust critique of a preliminary survey instrument (adapted from 4 substantial and rigorously tested instruments) was devised and undertaken. Subsequently, a pilot of the survey instrument was administered via Survey Monkey ${ }^{\circledR}$ to a purposive sample of practitioners, including the focus group participants, for verification and final amendment, which is reported in Jefferies, Davis and $\mathrm{Ke}$ (2015).

The questionnaire contained 25 questions using scales adapted from: Leuthesser and Kohli (1995) to determine the extent of initiating, signalling and disclosing behaviours; Morgan and Hunt (1994) to measure trust; Gundlach, Achrol and Mentzler (1995) to evaluate commitment and good faith \& fair dealing; and Rousseau and Tijoriwala (1998) to examine the relational conditions and benefits. The items in the scale reflect perceptions about the procurement partner across these aspects, which have been explained in the section of preliminary conceptual model. A specific question determined satisfaction with the partners. The details of the questionnaire are presented in the appendix. All items in these measures use a 5-point Likert scale with strongly disagree and strongly agree as anchors (Bryman, 2012).

The survey was electronically administered online via Survey Monkey ${ }^{\circledR}$ to a sample of 109 construction managers involved with project delivery. The sample was established with careful considerations of the population. As the information solicited requires in-depth knowledge and sound experience about project delivery, a purposive approach was adopted to select experts who should satisfy at least one of the following criteria:

Criterion 1: Having extensive working experience in construction projects in Australia.

Criterion 2: Having current/recent and direct involvement in project procurement of construction projects in Australia.

Criterion 3: Having a sound knowledge and understanding of the delivery of construction projects.

Analysis of the results using SPSS enabled the development and validation of the conceptual model. The main statistical methods used were Pearson's correlation analysis (Ke, Ling and Zou, 2015) to determine whether the hypotheses are true. Each pair of variables in the Pearson's correlation analysis comprised one dependent question and one independent question.

\section{Results and discussions}

A total of 53 valid responses were returned. It may be observed that a large majority of respondents are male, with only $10 \%$ of the respondents being female. Most of the respondents were between 30 and 60 years of age (28\% in the 30 - 39 years-old bracket, $25 \%$ in the $40-49$ year-old bracket and over 30\% in the 50 - 59 year-old bracket), overall $17 \%$ fell outside of this parameter with nearly $8 \%$ in the 21 - 29 year-old bracket and $9.5 \%$ over 60 years old. Over $22 \%$ of the respondents had in excess of 30 years' experience in project delivery, $15 \%$ of the respondents had 26 - 30 years' experience and a further $11.3 \%$ had 21 - 25 years' experience. It can hence be seen that the respondents were experienced in their roles.

With regard to the sample validity, it is observed that 53 sets of valid responses were received, representing a response rate of 48.6\%. Moreover, Cronbach's alpha value of research instrument is 0.961 , suggesting that the responses have a high internal consistency (Nunnally, 1978). It is therefore concluded that these data are reliable and further statistical analyses may be conducted.

Tables 1-5 (refer to Figure 1 for descriptions of the label numbers in Tables 1-5 and Figure 2) present the results of Pearson's correlation analyses for hypotheses 1-5 respectively. There is 
significant correlation in all tables, which proves that all research hypotheses are true. These significant correlations are further depicted in Figure 2. The arrows in Figure 2 denote the relationship of impacts tested from hypotheses. Therefore, please refer to Figure 1 for the descriptions of elements in the conceptual model and Figure 2 for the relationship of impacts.

Table 1: Correlation of relational conditions and benefits to unwritten agreement

\begin{tabular}{|c|c|c|c|c|}
\hline & & Q19 Trust & $\begin{array}{c}\text { Q20 } \\
\text { Commitment }\end{array}$ & $\begin{array}{l}\text { Q21 Good faith } \\
\text { and fair dealing }\end{array}$ \\
\hline \multirow{2}{*}{$\begin{array}{l}\text { Q14 Length of } \\
\text { relationship }\end{array}$} & Pearson Correlation & $0.368^{* *}$ & $0.391 * *$ & 0.226 \\
\hline & Significance & 0.007 & 0.004 & 0.104 \\
\hline \multirow{2}{*}{$\begin{array}{l}\text { Q22 Relational } \\
\text { benefits }\end{array}$} & Pearson Correlation & 0.253 & $0.314^{*}$ & 0.213 \\
\hline & Significance & 0.067 & 0.022 & 0.125 \\
\hline \multirow{2}{*}{$\begin{array}{l}\text { Q23 Relational } \\
\text { conditions }\end{array}$} & Pearson Correlation & $0.320^{*}$ & 0.215 & $0.302^{*}$ \\
\hline & Significance & 0.020 & 0.123 & 0.028 \\
\hline \multirow{2}{*}{$\begin{array}{l}\text { Q24 Intrinsic } \\
\text { benefits }\end{array}$} & Pearson Correlation & $0.477 * *$ & $0.493^{* *}$ & $0.335^{*}$ \\
\hline & Significance & 0.000 & 0.000 & 0.014 \\
\hline
\end{tabular}

**. Correlation is significant at the 0.01 level (2-tailed).

*. Correlation is significant at the 0.05 level (2-tailed).

Table 2: Correlation of relational conditions and benefits to unwritten behaviours

\begin{tabular}{|c|c|c|c|c|}
\hline & & $\begin{array}{l}\text { Q15 Initiating } \\
\text { behaviours }\end{array}$ & $\begin{array}{l}\text { Q16 Signalling } \\
\text { behaviours }\end{array}$ & $\begin{array}{l}\text { Q17 Disclosing } \\
\text { behaviours }\end{array}$ \\
\hline \multirow{2}{*}{$\begin{array}{l}\text { Q14 Length of } \\
\text { relationship }\end{array}$} & Pearson Correlation & 0.243 & 0.271 & $0.411 * *$ \\
\hline & Significance & 0.080 & 0.050 & 0.002 \\
\hline \multirow{2}{*}{$\begin{array}{l}\text { Q22 Relational } \\
\text { benefits }\end{array}$} & Pearson Correlation & $0.415^{* *}$ & 0.228 & 0.117 \\
\hline & Significance & 0.002 & 0.100 & 0.403 \\
\hline \multirow{2}{*}{$\begin{array}{l}\text { Q23 Relational } \\
\text { conditions }\end{array}$} & Pearson Correlation & $0.393^{* *}$ & $0.396^{* *}$ & 0.196 \\
\hline & Significance & 0.004 & 0.003 & 0.160 \\
\hline \multirow{2}{*}{$\begin{array}{l}\text { Q24 Intrinsic } \\
\text { benefits }\end{array}$} & Pearson Correlation & $0.431 * *$ & $0.559 * *$ & $0.418^{* *}$ \\
\hline & Significance & 0.001 & 0.000 & 0.002 \\
\hline
\end{tabular}

Table 3: Correlation of unwritten agreement to unwritten behaviours

\begin{tabular}{|c|c|c|c|c|}
\hline & & $\begin{array}{l}\text { Q15 Initiating } \\
\text { behaviours }\end{array}$ & $\begin{array}{l}\text { Q16 Signalling } \\
\text { behaviours }\end{array}$ & $\begin{array}{l}\text { Q17 Disclosing } \\
\text { behaviours }\end{array}$ \\
\hline \multirow[t]{2}{*}{ Q19 Trust } & Pearson Correlation & $0.658^{* *}$ & $0.699 * *$ & $0.755^{* *}$ \\
\hline & Significance & 0.000 & 0.000 & 0.000 \\
\hline \multirow{2}{*}{$\begin{array}{l}\text { Q20 } \\
\text { Commitment }\end{array}$} & Pearson Correlation & $0.430 * *$ & $0.586^{* *}$ & $0.597 * *$ \\
\hline & Significance & 0.001 & 0.000 & 0.000 \\
\hline \multirow{2}{*}{$\begin{array}{l}\text { Q21 Good faith } \\
\text { and fair dealing }\end{array}$} & Pearson Correlation & $0.295^{*}$ & $0.550 * *$ & $0.488^{* *}$ \\
\hline & Significance & 0.032 & 0.000 & 0.000 \\
\hline
\end{tabular}

Table 4: Correlation of unwritten agreement to satisfaction

\begin{tabular}{|lll|}
\hline \multirow{2}{*}{ Q19 Trust } & Pearson Correlation & $0.759^{* *}$ \\
\cline { 2 - 3 } & Significance & 0.000 \\
\hline Q20 Commitment & Pearson Correlation & $0.572^{* *}$ \\
\cline { 2 - 3 } & Significance & 0.000 \\
\hline $\begin{array}{l}\text { Q21 Good faith and fair } \\
\text { dealing }\end{array}$ & Pearson Correlation & $0.393^{* *}$ \\
\cline { 2 - 3 } & Significance & 0.004 \\
\hline
\end{tabular}


Table 5: Correlation of unwritten behaviours to satisfaction

\begin{tabular}{|lll|}
\hline \multirow{2}{*}{ Q15 Initiating behaviours } & Pearson Correlation & $0.640^{* *}$ \\
\cline { 2 - 3 } & Significance & 0.000 \\
\hline Q16 Signalling behaviours & Pearson Correlation & $0.593^{* *}$ \\
\cline { 2 - 3 } & Significance & 0.000 \\
\hline Q17 Disclosing behaviours & Pearson Correlation & $0.619^{* *}$ \\
\cline { 2 - 3 } & Significance & 0.000 \\
\hline
\end{tabular}



Figure 2: Validated conceptual model of the PC in construction

\section{Enabling factors}

In the conceptual model, relational conditions and relational benefits are the enabling factors of the PC, while the PC leads to the satisfaction of the partners. Questions 14, 22, 23 and 24 describe enabling factors and comprised, the duration of the relationship, procurement partners' relational benefits and conditions and intrinsic relationship benefits, these may be seen in Figure 1. Overall we describe these as Relational Conditions and Benefits or Enabling Factors.

The length of past relationships (Q14) is correlated with trust (Q19), commitment (Q20) and disclosing behaviours (Q17). When contracting parties have a longer past relationship, they are more likely to trust, be committed, act honestly, and disclose sensitive information with each other. This is consistent with Wong et al. (2008) who suggests trust develops from the confidence built upon understanding and knowledge that reveals the cognitive bearings of an organisation. Within a past relationship, the track record of past performance, the success of past interaction, and the extent of similarity or norms are the foundation of trust. Trust and friendship present in ongoing good relationships would provide further reasons for contracting parties to be more willing to communicate openly and compromise when problems arise ( $\mathrm{Ke}$, Ling and Zou, 2015). In PC terms a 'breach of the relationship', should it occur, would be less likely to cause 
abject failure. The managerial implication arising from the foregoing is that positive past relationships have a significant and positive affect on procurement partners.

Another enabling factor is the extent that perceived future tangible relational outcomes are forthcoming (Q22). Future tangible relational outcomes are correlated with commitment (Q20) and initiating behaviours (Q15). Knowing the promise of future tangible relational outcomes, contracting parties are likely to present commitment and participation in order to receive a tied future gain (Scholl, 1981). A number of empirical investigations also view commitment as a set of behavioural intentions derived from the expectation of future rewards (Davis and Walker, 2007). Initiating behaviours also displayed here reflect the extent that a construction firm has proactively taken the initiative to better understand their procurement partners, because they are revealing their commitment to the project, and in particular, the importance of expectations into the future (Ling et al., 2014b).

The extent that future appropriate resources and support is provided (Q23) is correlated with trust (Q19), good faith and fair dealing (Q21), initiating behaviours (Q15) and signalling behaviours (Q16). The promise of future appropriate resources and support explicates implicit expectations and determination, which initially enable the development of trust (Wong et al., 2008). The expectations and initial trust then motivate contracting parties to make an effort to better understand each other at project initiation and to behave fairly and cooperatively during the project's life cycle, because they believe in their procurement partner to provide efficient resources and support.

There is significant correlation between the factor of intrinsic relationship characteristics benefits (Q24) and the PC (Q15, Q16, Q17, Q19, Q20, and Q21). This echoes the findings of Ke, Ling and Zou (2015) that relationship attitude and strategies affect contracting behaviours. When contracting parties lean towards relational contracting, they tend to make decisions more based on relational mindset rather than explicit aspects of formal contracts (Ke, Ling and Zou, 2015). Van Gramberg (2006) also claimed that it is not advisable to rely on formal controls to manage transactions. Instead, relationships are utilised to handle problems because they are considered more flexible. Contracting parties that rely on relationships and trust when mitigating challenges, are more likely to have mutual understanding, open and effective communication, and strong interpersonal relations (Ke, Ling and Zou, 2015). The implication is that intrinsic relationship characteristics appear to be good predictors of contracting parties' unwritten agreement and behaviours. To achieve a productive strategy, a focus on the components of relationship characteristics is recommended.

Accordingly, and following the preceding discussion, we are able to confirm H1 and H2:

H1: Better relational conditions and benefits would lead to a higher level of unwritten agreement between contracting parties;

H2: Better relational conditions and benefits would lead to a higher extent of unwritten contracting behaviours between contracting parties.

\section{Internal interactions}

Following this we focus our attention on the interrelationship between Unwritten Agreement (Q19, Q20 and Q21) and Unwritten Contracting Behaviours (Q15, Q16 and Q17). We collectively refer to these as Internal Interactions. According to both Figure 2 and Table 3, trust (Q19) has a significant positive relationship with the three unwritten contracting behaviours, i.e. initiating behaviours (Q15), signalling behaviours (Q16) and disclosing behaviours (Q17). A definition of trust suggests the reason for this relationship: an actor's willingness to arrange and repose activities on another because of confidence that others will provide expected gratification (Scanzoni, 1979). Consequent to a manifestation of trust, contracting parties are likely to behave 
responsibly to fulfil not only the contractual obligations written in the contracts, but also the unwritten implied ones. A higher extent of initiating, signalling and disclosing behaviours are therefore expected when higher level of trust exists. Confirming this, George (1987) emphasised mutual trust as one of the major characteristics of successful management teams.

Commitment (Q20) is also correlated with initiating behaviours (Q15), signalling behaviours (Q16) and disclosing behaviours (Q17). Commitment is an important attitudinal predictor of employee behaviour and intentions (Becker et al., 1996). Since contracting parties with strong commitment are more attached and involved in the project, they also want to work cooperatively to ensure project success (Leung et al., 2004). It is understandable that the extent of initiating, signalling and disclosing behaviours is expected to be higher. The findings carry some important practice implications. First, it recommended assigning future projects to procurement partners who have a track record of implementing the projects with commitment. Second, it is recommended that clients check previous performance and satisfaction, which can encourage the partners to apply commitment in the subsequent tasks (Leung et al., 2004).

There is significant correlation between good faith and fair dealing (Q21) and unwritten contracting behaviours (Q15, Q16 and Q17). This suggests that when circumstances fall outside existing contractual principles, good faith and fair dealing may make a material difference. Jackson (2007) claimed that good faith and fair dealing is particularly important to result in an acceptable level of initiating and disclosing behaviours at the stage of pre-contractual negotiations when there is no contract imposing obligations on the contracting parties. During contract administration, signalling and disclosing behaviours in regards to technical arguments, disputes and changes are also subject to an extent of good faith (Jackson, 2007).

Accordingly, and following the foregoing discussion, we are able to confirm H3:

H3: When the level of unwritten agreement between contracting parties increase, unwritten contracting behaviours are adopted to a greater extent.

\section{Impact on satisfaction}

According to Tables 4 and 5, there are positive relationships between satisfaction (Q18) and all three unwritten agreement (Q19, Q20 and Q21) and all three contracting behaviours (Q15, Q16 and Q17). Although the whole concept of the PC in construction is not well reported to date, there is rich literature investigating each component. The results in Tables 4 and 5 reinforce the findings of previous research. For instance, Wong et al. (2008) indicated that trust within project team would certainly improve the project outcome of a construction project, where collaboration among contracting parties is essential in order to accomplish sophisticated tasks that require multi-party involvement; Davis and Walker (2007) proposed a relationship development model, which highlights the enhancement of relationships due to strong commitment with goal setting and outlining deliverables being the indicators; Dagenais (2007) advocated good faith and fair dealing as a key implied principle in construction contracts; Ning and Ling (2013) considered initiating behaviours (i.e. making an effort on mutual understanding) as critical success factors of project success; open and honest communication (i.e. signalling and disclosing behaviours) is also regarded as the key to smoothen the project process and avoid potential conflicts, thereby improving the satisfaction (Ling et al., 2014b). The findings suggest that the PC has a positive impact on construction projects, and underpins a contracting strategy where contracting parties place an emphasis on the relational exchanges beyond the contracts, which is in fact one of the main measures of satisfaction.

Finally, we predicted that:

H4: A higher level of unwritten agreement between contracting parties would lead to a higher satisfaction; and 
H5: A higher extent of unwritten contracting behaviours between contracting parties would lead to a higher satisfaction.

\section{Conclusion}

This research aimed to examine social exchanges via the psychological contract in construction procurement contracts so that partners can better manage their project relationships. In construction, the role of the PC has not been sufficiently explored; however, it has been extensively reviewed in business-related literature, which provides a foundation for the preliminary conceptual model of the PC in construction that we propose in this paper. The term PC refers to the unwritten agreement and behaviours between a construction firm and its upstream or downstream procurement partners. In the conceptual model, relational conditions and relational benefits are the enabling factors of the PC, while the PC leads to the satisfaction of the partners.

A questionnaire survey was conducted to a large sample of construction personnel. Respondents were requested to evaluate perceptions about the procurement partner across each component in the PC model. Pearson's correlation analysis was adopted to validate the hypotheses derived from the model. The results show that all the hypotheses are true. A validated model of the PC in construction was then developed based on the correlations among each component.

The findings add to the current knowledge base by showing that the PC model may have an effect on the project performance outcome and relationship quality among contracting parties. It is therefore important for contracting parties to pay attention to unwritten agreements and behaviours when managing construction projects. The findings contribute to practice by uncovering the relationships among relational conditions and benefits, the PC and procurement partners' satisfaction. The managerial implications of PC are that past relationships and relationship characteristics may be taken into account in the selection of the procurement partner, and the promise of future resources, support and tangible relational outcomes is also vital.

The research provides a greater understanding of the significant implications and managerial decisions leading to collaborative models of the firm-customer relationship. The taxonomies of PC developed can be used as a management tool to guide and support the adoption of relationship style contractual arrangements that reduce the likelihood of firms, together with their clients experiencing reduced productivity and enhanced project success.

Several limitations of the survey are acknowledged. It may be suggested that the small sample reduced the generalizability of the outcomes to some degree and it could be argued that their purposive characteristics compounded this with a limited breadth of construction delivery. However, this may be mitigated to some degree by the experience that was displayed by the overall sample. The focus of the research is novel and considers psychological contracts from a construction perspective and this essentially provides limited empirical data on the construction sector to draw from. However, the researcher team responsible for this paper believe that the foregoing research will provide a fruitful pool of discourse from which other researchers can build upon. Possible future research may focus on exploring some other elements that could be considered in the model of the PC as well as quantitatively assessing the impacts denoted in the arrows in Figure 2.

\section{References}

Australian Bureau of Statistics, 2015. Australian System of National Accounts, 2014-15, ABS Catalogue No. 5204.0, Canberra: Australian Bureau of Statistics. 
Bashir, S. and Nasir, M., 2013. Breach of psychological contract, organizational cynicism and union commitment: A study of hospitality industry in Pakistan. International Journal of Hospitality Management, 34, pp.61-5. doi: http://dx.doi.org/10.1016/i.ijhm.2013.02.004

Becker, T.E., Billings, R.S., Eveleth, D.M. and Gilbert, N.L., 1996. Foci and bases of employee commitment: Implications for job performance. Academy of management journal, 39(2), pp.464-82. doi: http://dx.doi.org/10.2307/256788

Bordia, S., Bordia, P. and Restubog, S.L.D., 2015. Promises from afar: a model of international student psychological contract in business education. Studies in Higher Education, 40(2), pp.212-32. doi: http://dx.doi.org/10.1080/03075079.2013.823935

Bryman, A., 2012. Social Research Methods. Oxford: Oxford University Press.

Chan, A.P.C. and Chan, A.P.L., 2004. Key performance indicators for measuring construction success. Benchmarking: an international journal, 11(2), pp.203-21.

Chen, W.T. and Chen, T.T., 2007. Critical success factors for construction partnering in Taiwan. International Journal of Project Management, 25(5), pp.475-84. doi: http://dx.doi.org/10.1016/j.ijproman.2006.12.003

Cheng, E.W., Li, H., Love, P.E. and Irani, Z., 2001. Network communication in the construction industry. Corporate Communications: An International Journal, 6(2), pp.61-70. doi: http://dx.doi.org/10.1108/13563280110390314

Cheung, S.O., Yiu, K.T. and Chim, P.S., 2006. How relational are construction contracts? Journal of Professional Issues in Engineering Education and Practice, 132(1), pp.48-56. doi: http://dx.doi.org/10.1061/(ASCE)10523928(2006)132:1(48)

Dagenais, D.A., 2007. Introduction to good faith in construction contracts. Construction Management and Economics, 25(7), pp.715-21.doi: http://dx.doi.org/10.1080/01446190701393000

Dainty, A.R.J. and Loosemore, M., 2013. Human Resource Management in Construction: Critical Perspectives. Oxford, UK: Taylor \& Francis Group.

Dainty, A.R.J., Raiden, A.B. and Neale, R.H., 2004. Psychological contract expectations of construction project managers. Engineering, Construction and Architectural Management, 11(1), pp.33-44. doi: http://dx.doi.org/10.1108/09699980410512647

Davis, P.R. and Love, P.E.D., 2011. Alliance contracting: adding value through relationship development. Engineering, Construction and Architectural Management, 18(5), pp.444-61. doi: http://dx.doi.org/10.1108/09699981111165167

Davis, P.R. and Walker, D.H.T., 2007. Trust, commitment and mutual goals in Australian construction industry project alliances. In: D.H.T. Walker and S. Rowlinson, eds. Procurement Systems: A Cross-Industry Project Management Perspective. United Kingdom: Taylor and Francis. pp.378-99.

Department of Infrastructure and Regional Development, 2015. National Alliance Contracting Guidelines: Policy Principles. Canberra: Commonwealth of Australia.

Doloi, H.. 2013. Empirical Analysis of Traditional Contracting and Relationship Agreements for Procuring Partners in Construction Projects. Journal of Management in Engineering, 29(3), pp.224-35. doi: http://dx.doi.org/10.1061/(ASCE)ME.1943-5479.0000141

Fulford, R. and Standing, C., 2014. Construction industry productivity and the potential for collaborative practice. International Journal of Project Management, 32(2), pp.315-26. doi: http:/ /dx.doi.org/10.1016/j.ijproman.2013.05.007

George, P.S., 1987. Team building without tears. Personnel Journal, 66(11), pp.122-29.

Guest, D.E. and Conway, N., 2002. Communicating the psychological contract: an employer perspective. Human resource management journal, 12(2), pp.22-38. doi: http://dx.doi.org/10.1111/j.1748-8583.2002.tb00062.x

Guest, D.E. and Conway, N., 2004. Employee well-being and the psychological contract: a report for the CIPD. Chartered Institute of Personnel and Development, London.

Gundlach, G.T., Achrol, R.S. and Mentzer, J.T., 1995. The structure of commitment in exchange. Journal of Marketing, 59(1), pp.78-92. doi:http://dx.doi.org/10.2307/1252016

Jackson, S., 2007. Good Faith in Construction-Will it Make a Difference and is it Worth the Trouble? Construction Law Journal, 23(6), pp.420-35.

Jefferies, M., Davis, P.R. and Ke, Y., 2015. An investigation of psychological contracts in construction procurement. In: Leveraging knowledge and innovation for sustainable construction and development. CIB conference Going North for Sustainability London Southbank University. 23-25 November 2015. London, UK: IBEA Publications.

Jelodar, M.B., Yiu, T.W. and Wilkinson, S., 2016. A conceptualisation of relationship quality in construction procurement. International Journal of Project Management, 34(6), pp.997-1011. doi: http://dx.doi.org/10.1016/j.ijproman.2016.03.005

Jha, K. and Iyer, K., 2007. Commitment, coordination, competence and the iron triangle. International Journal of Project Management, 25(5), pp.527-40. doi: http://dx.doi.org/10.1016/j.ijproman.2006.11.009

Jin, X.H. and Ling, F.Y.Y., 2005. Constructing a framework for building relationships and trust in project organizations: two case studies of building projects in China. Construction Management and Economics, 23(7), pp.68596. doi: http://dx.doi.org/10.1080/01446190500127039

Ke, Y., Ling, F.Y.Y. and Zou, P.X.W., 2015. Effects of Contract Strategy on Interpersonal Relations and Project Outcomes of Public-Sector Construction Contracts in Australia. Journal of Management in Engineering, 31(4), 04014062. $\quad$ http://hdl.handle.net/1959.13/1309379. doi:http://dx.doi.org/10.1061/(ASCE)ME.1943$\underline{5479.0000273}$ 
Lahdenperä, P., 2012. Making sense of the multi-party contractual arrangements of project partnering, project alliancing and integrated project delivery. Construction Management and Economics, 30(1), pp.57-79. doi: http://dx.doi.org/10.1080/01446193.2011.648947

Leung, M.Y., Chong, A., Ng, S.T. and Cheung, M.C.K., 2004. Demystifying stakeholders' commitment and its impacts on construction projects. Construction Management and Economics, 22(7), pp.701-15. doi: http://dx.doi.org/10.1080/0144619042000300736

Leung, M.Y., Yu, J. and Chong, M.L.A., 2015. Effects of Stress and Commitment on the Performance of Construction Estimation Participants in Hong Kong. Journal of Construction Engineering and Management, 142(2), 04015081.doi: http://dx.doi.org/10.1061/(ASCE)CO.1943-7862.0001059

Leuthesser, L. and Kohli, A.K., 1995. Relational behavior in business markets: Iplications for relationship management. Journal of Business Research, 34(3), pp.221-33. doi: http://dx.doi.org/10.1016/0148-2963(95)00006-E

Ling, F.Y.Y., Ke, Y., Kumaraswamy, M.M. and Wang, S., 2014. Key Relational Contracting Practices Affecting Performance of Public Construction Projects in China. Journal of Construction Engineering and Management, 140(1), 04013034. doi: http://dx.doi.org/10.1061/(ASCE)CO.1943-7862.0000781

Ling, F.Y.Y., Ong, S.Y., Ke, Y., Wang, S. and Zou, P.X.W., 2014b. Drivers and barriers to adopting relational contracting practices in public projects: comparative study of Beijing and Sydney. International Journal of Project Management, 32(2), pp.275-85. doi: http://dx.doi.org/10.1016/j.ijproman.2013.04.008

Liu, J., Love, P., Davis, P., Smith, J. and Regan, M., 2014. Life-Cycle Critical Success Factors for Public-Private Partnership Infrastructure Projects. Journal in Management in Engineering, 31(5), 04014073. doi: http://dx.doi.org/10.1061/(ASCE)ME.1943-5479.0000307

Lloyd-Walker, B.M., Mills, A.J. and Walker, D.H.T., 2014. Enabling construction innovation: the role of a no-blame culture as a collaboration behavioural driver in project alliances. Construction Management and Economics, 32(3), pp.229-45. doi:http://dx.doi.org/10.1080/01446193.2014.892629

Love, P.E., Davis, P.R., Cheung, S.O. and Irani, Z., 2011. Causal discovery and inference of project disputes. IEEE Transactions on Engineering Management, 58(3), pp.400-11. doi: http://dx.doi.org/10.1109/TEM.2010.2048907

Love, P.E., O'Donoghue, D., Davis, P.R. and Smith, J., 2014. Procurement of Public Sector Facilities: Views of Early Contractor Involvement. Facilities, 32(9/10), pp.460-71. doi: http://dx.doi.org/10.1108/F-03-2012-0020

Lu, P., Guo, S., Qian, L., He, P. and Xu, X., 2015. The effectiveness of contractual and relational governances in construction projects in China. International Journal of Project Management, 33(1), pp.212-22. doi:http://dx.doi.org/10.1016/j.ijproman.2014.03.004

Meng, X., 2010. Assessment framework for construction supply chain relationships: development and evaluation. International Journal of Project Management, $28(7), \quad$ pp.695-707. doi: http://dx.doi.org/10.1016/j.ijproman.2009.12.006

Morgan, R.M. and Hunt, S.D., 1994. The commitment-trust theory of relationship marketing. Journal of Marketing, 58(3), pp.20-38. doi:http://dx.doi.org/10.2307/1252308

Ning, Y. and Ling, F.Y.Y., 2013. Comparative study of drivers of and barriers to relational transactions faced by public clients, private contractors and consultants in public projects. Habitat International, 40, pp.91-9. doi:http://dx.doi.org/10.1016/j.habitatint.2013.02.007

Nunnally, J.C., 1978. Psychometric Theory. New York: McGraw-Hill.

Rahman, M.M. and Kumaraswamy, M.M.. 2004. Contracting relationship trends and transitions. Journal of Management in Engineering, 20(4), pp.147-61 doi: .http://dx.doi.org/10.1061/(ASCE)0742-597X(2004)20:4(147)

Raiden, A.B., Dainty, A.R.J. and Neale, R.H., 2009. Employee resourcing in the construction industry: strategic considerations and operational practice. London: Spon Press.

Richardson, D., 2014. Productivity in the construction industry. (TB33 August 2014 1836-9014) Canberra, ACT: The Australia Institute.

Rousseau, D.M., 1990. New hire perceptions of their own and their employer's obligations: A study of psychological contracts. Journal of organizational behavior, 11(5), pp.389-400. doi: http://dx.doi.org/10.1002/job.4030110506

Rousseau, D.M., 1995. Psychological contracts in organizations: Understanding written and unwritten agreements. Thousand Oaks, California: Sage Publications Inc.

Rousseau, D. M. and Tijoriwala, S.A., 1998. Assessing psychological contracts: Issues, alternatives and measures. Journal of organizational Behavior, 19(S1), pp.679-95. doi: http://dx.doi.org/10.1002/(SICI)10991379(1998)19:1+<679::AID-JOB971>3.0.CO;2-N

Sariola, R. and Martinsuo, M., 2016. Enhancing the supplier's non-contractual project relationships with designers. International Journal of Project Management, 34(6), pp.923-36. doi: http://dx.doi.org/10.1016/j.ijproman.2016.04.002

Scanzoni, J., 1979. Social Exchange and Behavioral Interdependence. In: R.L. Burgess and T.L. Huston, eds. Social Exchange in Developing Relationships. New York: Academic Press, pp.61-98. doi: http://dx.doi.org/10.1016/B9780-12-143550-9.50009-4

Scholl, R.W., 1981. Differentiating Organizational Commitment From Expectancy as a Motivating Force. Academy of Management Review, 6(4), pp.589-99. doi: http://dx.doi.org/10.2307/257637 and http://dx.doi.org/10.5465/AMR.1981.4285698

Smiley, J.P., Fernie, S. and Dainty, A., 2014. Understanding construction reform discourses. Construction Management and Economics, 32(7-8), pp.804-15. doi: http://dx.doi.org/10.1080/01446193.2014.909049 
Sparrow, P. and Marchington, M., 1998. Human resource management: the new agenda, Financial Times Pitman Publishing. Van Gramberg, B., 2006. Managing workplace conflict: Alternative dispute resolution in Australia. Annandale, NSW: The Federation Press.

Walker, A., 2010. The development and validation of a psychological contract of safety scale. Journal of safety research, 41(4), pp.315-21. doi: http://dx.doi.org/10.1016/j.jsr.2010.06.002

Walker, A., 2013. Outcomes associated with breach and fulfillment of the psychological contract of safety. Journal of safety research, 47, pp.31-7.doi: http://dx.doi.org/10.1016/j.jsr.2013.08.008

Walker, A. and Hutton, D.M., 2006. The application of the psychological contract to workplace safety. Journal of safety research, 37(5), pp.433-41.doi: http://dx.doi.org/10.1016/i.jsr.2006.06.001

Walker, D.H.T., Harley, J. and Mills, A., 2015. Performance of project alliancing in Australasia: a digest of infrastructure development from 2008 to 2013. Construction Economics and Building, 15(1), pp.1-18. doi:http://dx.doi.org/10.5130/ajceb.v15i1.4186

Walker, D.H.T. and Lloyd-Walker, B.M., 2015. Collaborative Project Procurement Arrangements. Project Management Institute.

Wong, W.K., Cheung, S.O., Yiu, T.W. and Pang, H.Y., 2008. A framework for trust in construction contracting. International Journal of Project Management, 26(8), pp.821-29. doi: http://dx.doi.org/10.1016/i.ijproman.2007.11.004

Wyse, D.D. and Malik, S., 2005. Audit Contract Provisions and Real-Time Cost Reporting in Construction Contracting. Journal of Professional Issues in Engineering Education and Practice, 131(4), pp.297-300. doi: http://dx.doi.org/10.1061/(ASCE)1052-3928(2005)131:4(297)

Yang, H. and Fu, H., 2013. Psychological Contract Structure of Banks and Credit Customers Based on the Empirical Study of Banking Industry in Jiangxi Province. Journal of Applied Sciences, 13(17), pp.3431-434. doi: http://dx.doi.org/10.3923/jas.2013.3431.3434

\section{Appendix: Simplified questionnaire}

1. What is your gender?

2. Which category below includes your age?

3. How many year of experience do you have in project delivery?

4. What is your job role?

5. What sector of the construction industry do you come from?

6. About how many employees work at your organization?

7. Approximately what is your organisation's annual turnover?

8. What best describes your place of work?

9. How would you best describe the facility?

10. What was the project's original value at the award of the contract?

11. What type of procurement method was used for the project?

12. What type of tendering was used to select your organisation for the project?

13. To assist us please identify if in answering the following questions you are thinking about an upstream relationship (for example a client), or a downstream relationship (for example a specialist contractor). Please retain this thought through the remainder of the questionnaire.

14. How long has this relationship been in place?

15. Please check the box adjacent to each statement that reflects your perception of your procurement partner's initiating behaviours (proactively taken the initiative to better understand you) whilst working with you on a recent project.

- In the project, our major partner spends time learning how to help me lower costs 
- In the project, our major partner spend time trying to help me gain maximum benefit from their input

- In the project, our major partner makes an effort to keep themselves abreast of my changing needs

- In the project, our major partner shows an active interest in helping me become more competitive

- In the project, our major partner keeps themselves abreast with changes in my competitive environment

- In the project, our major partners show an active interest in trying to understand how my organisation works

16. Please check the box adjacent to each statement that reflects your perception of your procurement partner's signalling behaviours (the extent partners divulge product or pricing information in advance) whilst working with you on a recent project.

- In the project, our major partner gives me ample notice of any planned changes

- In the project, our major partner does a good job of notifying me of advance delivery schedules

- In the project, our major partner informs me of any changes in procedures well ahead of time

- In the project, our major partner informs me early of any plans to change their team

- In the project, our major partner discusses plans to change the quality of the product

- In the project, our major partner gives plenty of notice if the level of service is about to change

17. Please check the box adjacent to each statement that reflects your perception of your procurement partner's disclosing behaviours (the extent that partners reveal sensitive information about themselves and or their operations) whilst working with you on a recent project.

- In the project, our major partner alters the facts slightly

- In the project, our major partner keeps me informed of new developments

- In the project, our major partner tends to sidestep any talk about weaknesses in their organisation

- In the project, our major partner gives us a clear picture of what goes on behind-thescenes in their organisation

- In the project, our major partner communicates well their expectations of my organisation

18. Please check the box adjacent to each statement that reflects your perception of your procurement partner's satisfaction whilst working with you on a recent project.

- In the project, our major partner is committed to my overall relationship with them

- In the project, our major partner wishes there were more partners like us

- In the project, our major partner would like our relationship with them to continue in the coming years

- In the project, our major partner feels it is a pleasure working with me

- In the project, our major partner feels there is always some problem with our relationship

19. Please check the box adjacent to each statement that reflects your perception of your procurement partner's trust whilst working with you on a recent project.

- In the project, our major partner is reliable and they do what they say they will

- In the project, our major partner is perfectly honest and truthful 
- In the project, our major partner can be trusted completely

- In the project, our major partner can be counted on to do what is right

- In the project, our major partner is always faithful

- In the project, our major partner is someone that I have great confidence in

- In the project, and major partner has high integrity

20. Please check the box adjacent to each statement that reflects your perception of your procurement partner's commitment whilst working with you on a recent project.

- In the project, our major partner is something that I am dedicated to

- In the project, our major partner is very important

- In the project, our major partner is of little significance

- In the project, our major partner is something to be maintained indefinitely

- In the project, our major partner is very much like family

- In the project, our major partner is something that I really care about

- In the project, our major partner deserves maximum attention

21. Please check the box adjacent to each statement that reflects your perception of your procurement partner's good faith and fair dealing (the level of honesty, professionalism and collegiality that is given) whilst working with you on a recent project

- Our major partner promised a collaborative work environment between our organisations

- Our major partner promised candid and open feedback within our relationship

- Our major partner promised respect for our organisations efforts within the relationship

- Our major partner promised a cooperative working relationship between our organisations

- Our major partner promised honest treatment towards our organisation in the relationship

- Our major partner promised professional and collegiality directed toward our organisation

22. Please check the box adjacent to each statement that reflects your perception of your procurement partner's relational benefits (the extent that perceived future tangible relational outcomes are forthcoming) whilst working with you on a recent project

- Our major partner promised attractive benefits to our organisation to secure future work

- Our major partner promised positive financial returns tied to our organisation's performance

- Our major partner promised good opportunities for advancing our organisation

- Our major partner promised incentives linked to their organisation's performance

23. Please check the box adjacent to each statement that reflects your perception of your procurement partner's relational conditions (the extent that future appropriate resources and support is provided) whilst working with you on a recent project

- Our major partner promised the tools necessary for our organisation to perform its role effectively

- Our major partner promised an environment that promotes the opportunity for our organisation to learn

- Our major partner promised materials and equipment needed by our organisation to perform its role 
- Our major partner promised a clean and safe work environment for our organisation to operate in

- Our major partner promised the necessary skill development for our organisations employees

- Our major partner promised further training for employees within our organisation

- Our major partner promised further information for employees within our organisation

24. Please check the box adjacent to each statement that reflects your perception of your procurement partner's intrinsic relationship characteristics benefits (reflects the extent of total autonomy and responsibility given for their actions in the value chain) whilst working with you on a recent project

- Our major partner promised a relationship role that is interesting to our organisation

- Our major partner promised a meaningful role for our firm within the overall relationship

- Our major partner promised our organisation high levels of autonomy

- Our major partner promised a role that is challenging to our organisation

- Our major partner promised a role that has high levels of responsibility 